\title{
The pancreas in recent-onset Type 1 (insulin-dependent) diabetes mellitus: insulin content of islets, insulitis and associated changes in the exocrine acinar tissue
}

\author{
A. K. Foulis and J. A. Stewart \\ Department of Pathology, Western Infirmary, Glasgow, UK
}

\begin{abstract}
Summary. The pancreatic autopsy findings of 11 children with Type 1 (insulin-dependent) diabetes mellitus are presented. Nine children died within $24 \mathrm{~h}$ of initial presentation. In these 'recent-onset' diabetic patients many islets were shrunken and insulin-deficient. However, large islets containing B cells were present also. Insulitis was present in eight recent-onset diabetic subjects; in these, $18 \%$ of insulin-containing islets were inflamed, but only $1 \%$ of insulin-deficient islets were thus affected. This finding supports the concept of an immunologically
\end{abstract}

mediated destruction of B cells in the pathogenesis of Type 1 diabetes. Severe acinar cell atrophy was present surrounding insulin-deficient islets, but acinar tissue around insulin-containing islets was normal. These exocrine changes are thought to be related to islet-exocrine vascular connections and the effects of the various islet hormones on pancreatic acini.

Key words: Type 1 diabetes, islets of Langerhans, insulitis, exocrine pancreas, autopsy study.
The pathology of the pancreatic islets in Type 1 diabetes mellitus of less than 6 months' duration ('recent-onset diabetes') has been described in detail [1-5]. Two obvious populations of islet were present. Insulin-deficient islets were shrunken but contained normal numbers of glucagon-secreting $\mathrm{A}$ cells and somatostatin-secreting $\mathrm{D}$ cells [4]. Islets containing insulin-secreting B cells were often hypertrophic and were rare in the pancreases of patients with prolonged diabetes (greater than 6 months" duration) [4]. With one exception [2], insulitis was demonstrable in the majority of cases of recent-onset Type 1 diabetes $[1,3,4]$.

The pancreases from patients who had had Type 1 diabetes for many years were often reduced in weight [5, 1], and showed histological evidence of exocrine atrophy [6], but no such changes have been described in recent-onset diabetes.

The present study re-examines the pathological features of the islets in recent-onset Type 1 diabetes and describes the appearance of the pancreatic exocrine tissue adjacent to the two types of islet.

\section{Patients and methods}

\section{Patients}

A 30-year retrospective survey of autopsies performed on patients with Type 1 diabetes at the Royal Hospital for Sick Children in Glas- gow revealed 11 cases (Table 1). Nine of these children died within $24 \mathrm{~h}$ of establishing the diagnosis. The two patients with more prolonged disease had received regular insulin therapy. All the recent-onset patients and the child with diabetes of 6 years' duration died in hyperglycaemic ketoacidotic coma. The remaining child died of lobar pneumonia. For the purposes of this study each diabetic subject was paired with an age-matched control patient who had died of a disease unrelated to the pancreas (three meningitis, three acute leukaemia, one pneumonia, one tuberculosis, one status epilepticus, one cerebral tumour, one adrenal hypoplasia).

\section{Methods}

Paraffin blocks of pancreas were available in all cases. Serial sections $(5 \mu \mathrm{m})$ were cut from each block and consecutive sections stained by haematoxylin and eosin, by an indirect immunoperoxidase method for insulin-containing B cells [7] and by a peroxidase-antiperoxidase (PAP) technique for glucagon-containing A cells, somatostatin-containing D cells and pancreatic polypeptide-containing (PP) cells [8]. The specific antisera were used at the following dilutions: guinea-pig anti-insulin serum 1:2500 (Miles Laboratories, Slough, Bucks, UK), rabbit anti-glucagon serum, 1:2500 (Milab, Metachem Diagnostics, Northampton, UK), rabbit anti-somatostatin serum, 1:3500 (Dako, Mercia Brocades, Weybridge, UK), and rabbit anti-pancreatic polypeptide serum, 1:640 (Milab). The rabbit PAP complex (Dako) was used at a dilution of $1: 300$ and the rabbit anti-guinea-pig immunoglobulin peroxidase conjugate (Dako) was diluted 1:50, in the technique for demonstrating insulin. Control studies were performed, firstly with specific antibodies previously adsorbed with an excess of the corresponding antigen, and secondly with the substitution of pooled, diluted guinea-pig or rabbit sera instead of the primary antiserum. 
Table 1. Insulin content of islets in relation to insulitis in the post mortem pancreas of diabetic children

\begin{tabular}{|c|c|c|c|c|c|c|c|c|c|}
\hline Case & $\begin{array}{l}\text { Age } \\
\text { (years) }\end{array}$ & Sex & $\begin{array}{l}\text { Duration } \\
\text { of symptoms } \\
\text { (weeks) }\end{array}$ & $\begin{array}{l}\text { Weight of } \\
\text { pancreas } \\
\text { (g) }\end{array}$ & $\begin{array}{l}\text { No. of blocks } \\
\text { of pancreas }\end{array}$ & $\begin{array}{l}\text { Total no. of } \\
\text { insulin- } \\
\text { containing } \\
\text { islets }\end{array}$ & $\begin{array}{l}\text { No. of insulin- } \\
\text { containing islets } \\
\text { with insulitis }\end{array}$ & $\begin{array}{l}\text { Total no. } \\
\text { of insulin- } \\
\text { deficient } \\
\text { islets }\end{array}$ & $\begin{array}{l}\text { No. of insulin- } \\
\text { deficient islets } \\
\text { with insulitis }\end{array}$ \\
\hline
\end{tabular}

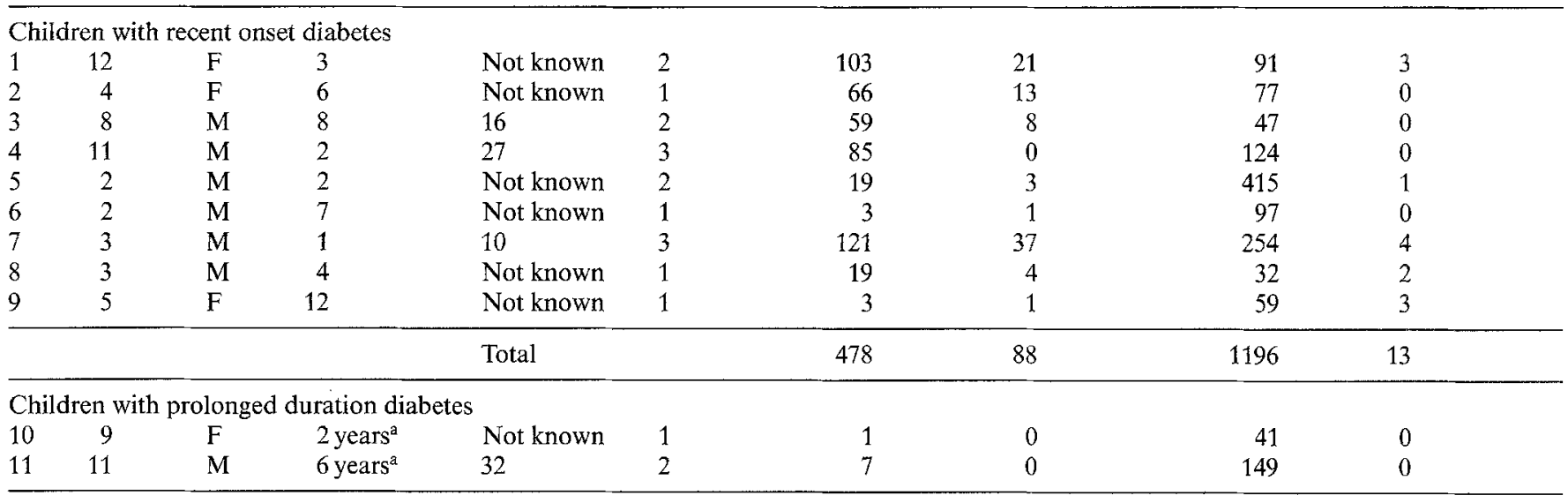

$\left.\begin{array}{l}\text { Percentage of insulin-containing islets with insulitis in recent onset diabetes }=18.4 \% \\ \text { Percentage of insulin-deficient islets with insulitis in recent onset diabetes }=1.1 \%\end{array}\right\} p<0.001, \chi^{2}$ test.

${ }^{a}$ period of insulin treatment

\section{Results}

Two populations of islets could be discerned according to whether or not B cells were demonstrated immunohistochemically (Fig. 1). Insulin-deficient islets were smaller than normal and were composed of normal numbers of $A, D$ and $P P$ cells when compared with controls. All the cells were labelled if anti-glucagon, antisomatostatin and anti-pancreatic polypeptide sera were applied simultaneously, indicating that there was not a population of cells containing either a fourth hormone or no hormone. Occasional insulin-deficient islets were obviously fibrosed. By contrast, insulin-containing islets were more heterogeneous in appearance. In eight of the nine pancreases from recent-onset subjects, the islets were generally larger than normal and many contained hypertrophic B cells, some of which showed marked polyploidy (Fig. 1 b). In the case of patients 5, 10 and 11 no hypertrophy of insulin-containing islets was seen. Some insulin-containing islets showed a marked reduction in the numbers of B cells. These islets were usually fibrosed. The other hormones were present in all insulin-containing islets in their normal proportions, when compared with controls.

The relative numbers of insulin-deficient and insulin-containing islets in the pancreases of the diabetic patients are given in Table 1 . The distribution of the two types of islet within the pancreases was not entirely random. Sometimes there was a striking lobular distribution, with one pancreatic lobule having only insulincontaining islets and an adjacent one containing only insulin-deficient islets (Fig. 2). All seven insulin-containing islets in the pancreas of patient 11 were present in one lobule. Isolated B cells, present in acinar tissue were a normal finding in the control pancreases; these were absent in the diabetic subjects except in the vicinity of insulin-containing islets.

Insulitis was present in eight pancreases of recentonset patients. The infiltrate consisted predominantly of lymphocytes with an occasional admixture of polymorphs. Plasma cells were absent. Insulitis varied in frequency quite markedly from patient to patient and it was absent from the two subjects with prolonged duration of diabetes (Table 1). An important finding in the pancreases of recent-onset diabetic patients was that $18 \%$ of insulin-containing islets but only $1 \%$ of the insulin-deficient islets were affected by insulitis. In several cases a spectrum of changes could be seen from (1) large insulin-containing islets with a minimal peripheral inflammatory cell infiltrate (Fig. 1b) to (2) a marked diffuse infiltrate associated with evidence of cellular necrosis (karyorrhexis), reduced numbers of B cells and general collapse of the islet to (3) shrunken islets with cords of insulin-deficient endocrine cells separated by fibrous tissue and a residual inflammatory cell infiltrate.

The changes in the exocrine tissue were striking. Insulin-containing islets were surrounded by normal acinar tissue, while insulin-deficient islets were surrounded by atrophic acini. The atrophic acinar cells were smaller and contained many fewer zymogen granules than normal. This relationship between the presence or absence of B cells in an islet and the appearance of the adjacent acini was so marked that the insulin status of an islet could be predicted precisely by observing the surrounding exocrine tissue on a haematoxylin and eosin stained section. Even an islet showing severe necrosis and insulitis was surrounded by normal exocrine tissue so long as insulin-containing cells were still present within the islet. Areas of exocrine pancreas containing only one type of islet were either normal or uni- 


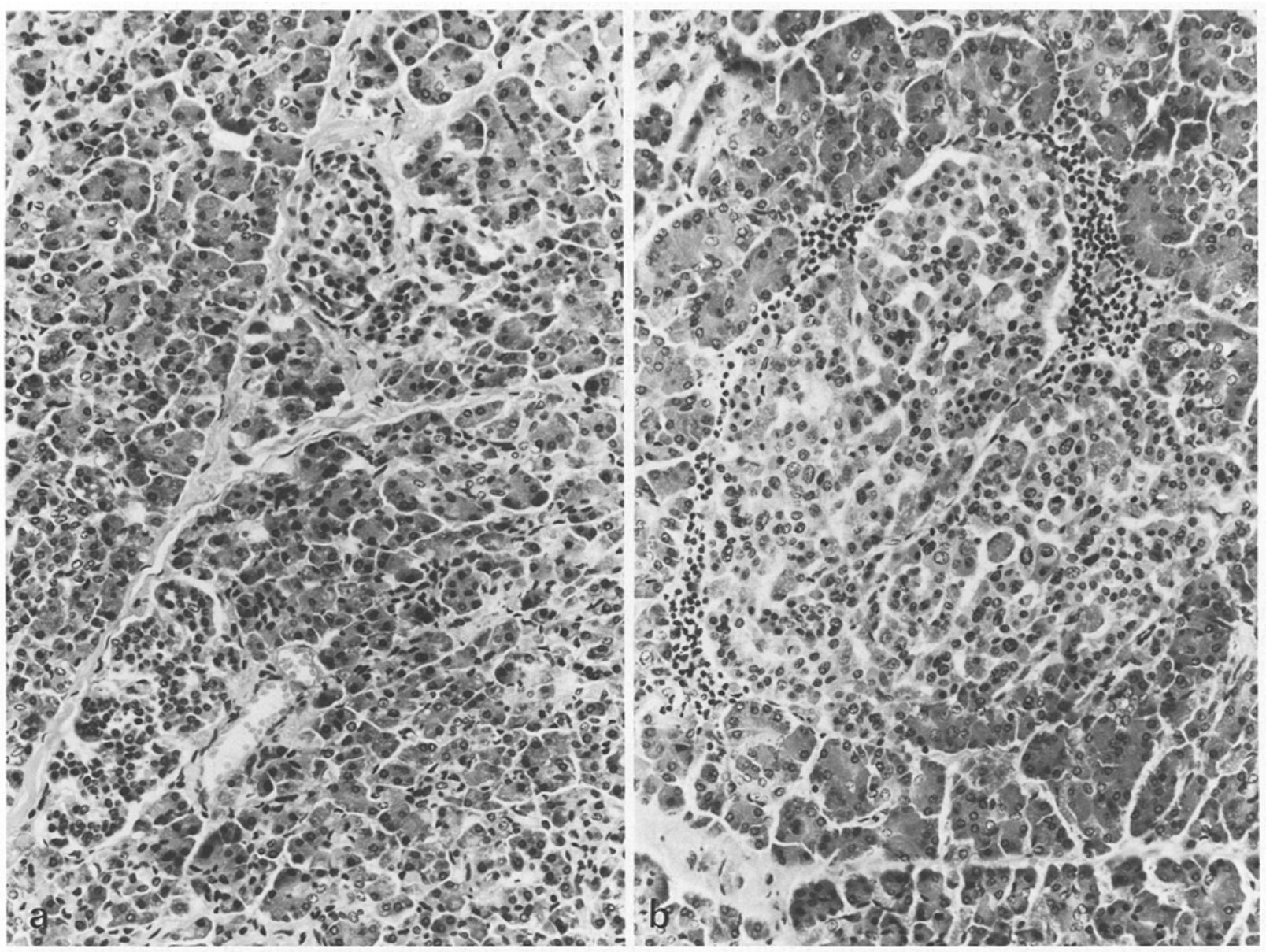

Fig. 1. a Two insulin-deficient islets are shown. They are shrunken and poorly defined from exocrine tissue. By comparison $\mathbf{b}$ shows a large insulin-containing islet with hypertrophic B cells and a peripheral chronic inflammatory cell infiltrate (insulitis) (haematoxylin and eosin, $\times 230$ )

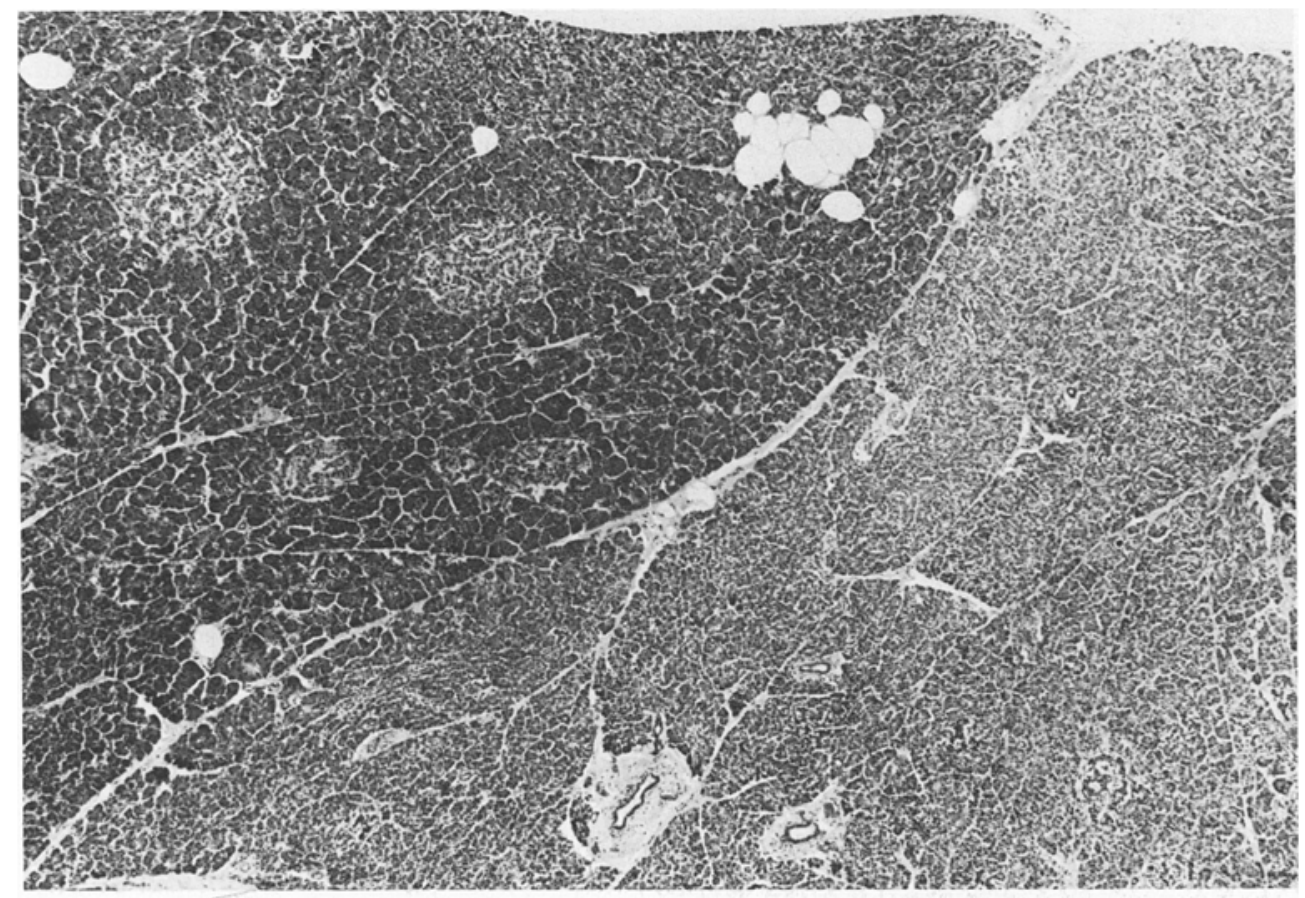

Fig. 2. The junction between two pancreatic lobules is shown. In the one on the left large, well defined, insulin-containing islets are present and the exocrine tissue is normal. On the right ill-defined, insulin-deficient islets are present and there is marked acinar atrophy (haematoxylin and eosin, $\times 51$ ) 


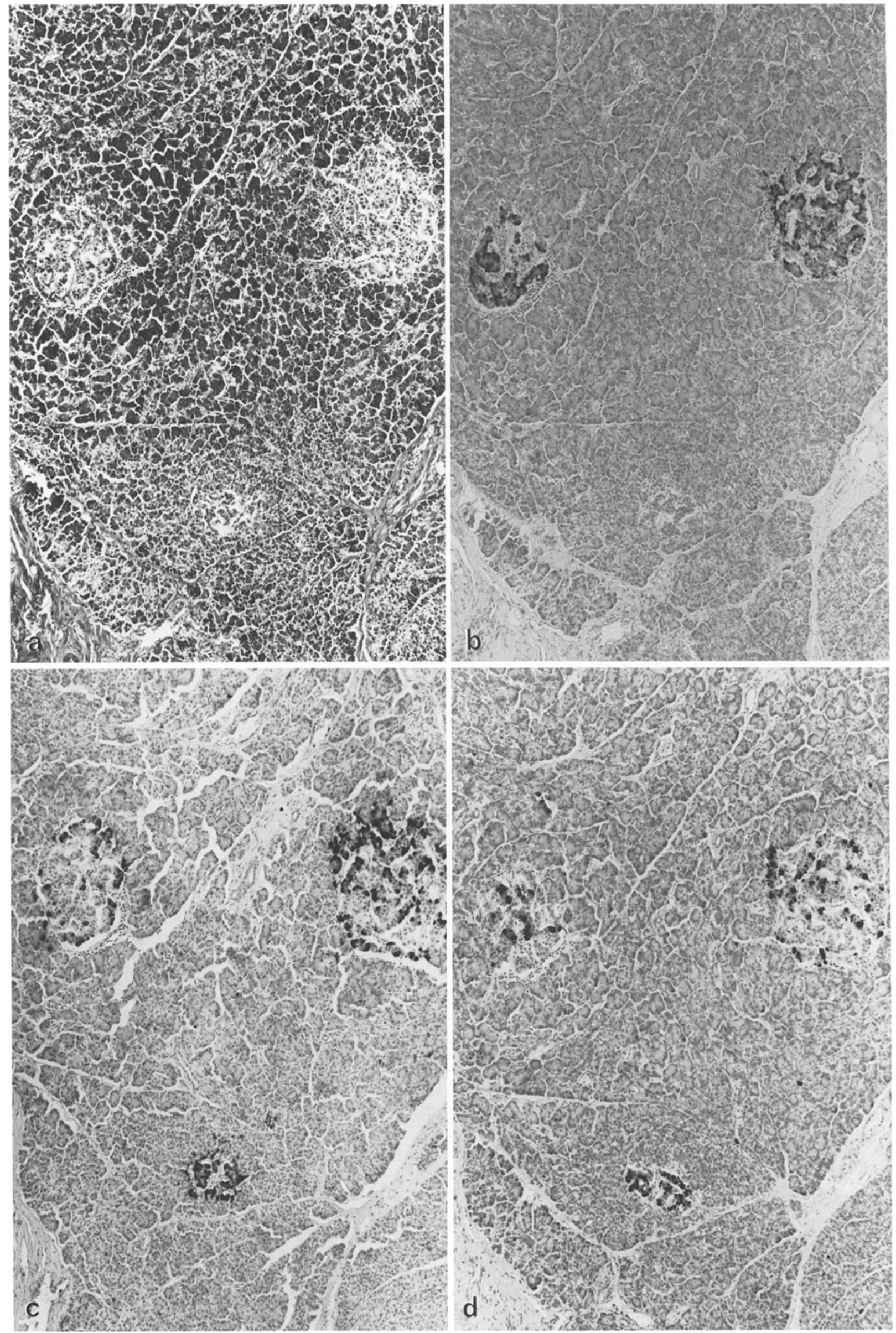

Fig. 3. a Two insulin-containing islets are shown on the top of the figure. A small insulin-deficient islet is present below them surrounded by atrophic exocrine tissue (haematoxylin and eosin, $\times 91$ ). Serial sections have been immunostained for $\mathbf{b}$ insulin, $\mathbf{c}$ glucagon and $\mathbf{d}$ somatostatin. Pan- 


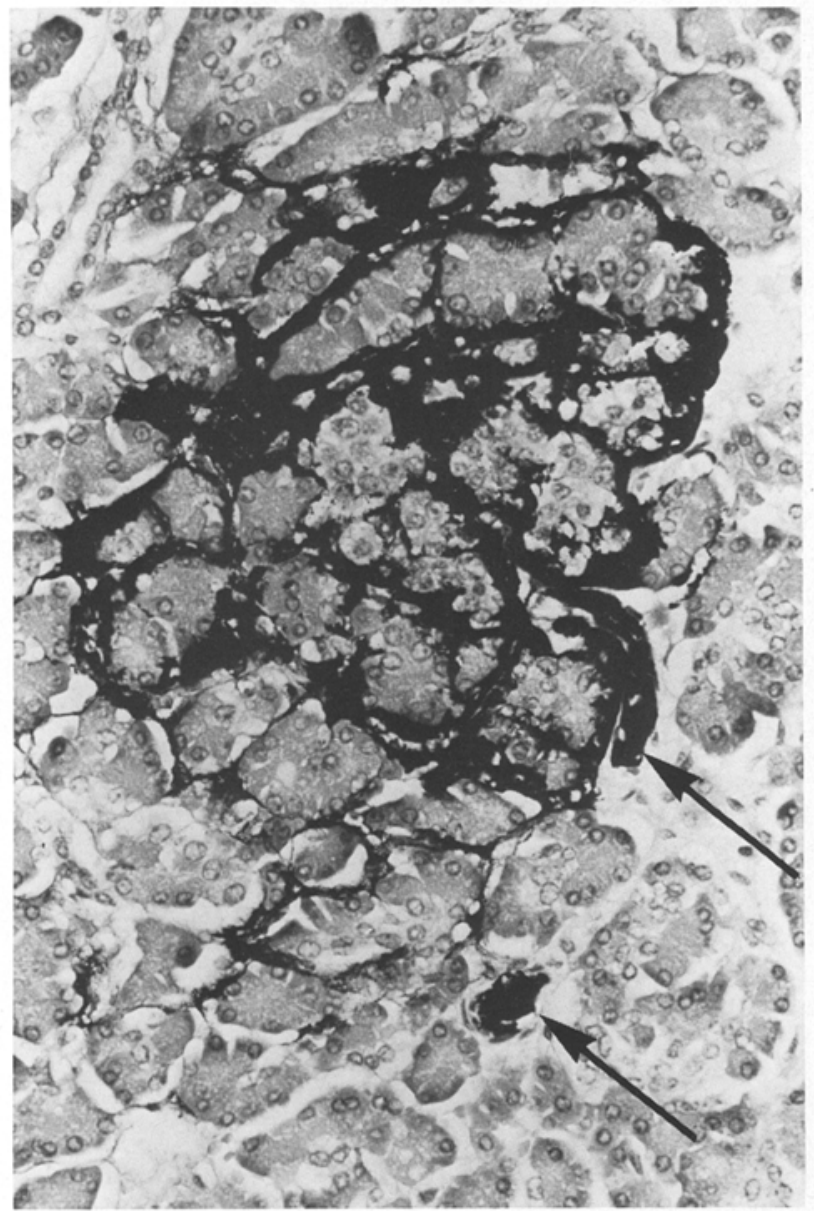

Fig.4. Islet blood supply: an Indian Ink injection study of the arterial system of the pancreas was performed on the pancreas of a 22-yearold normal male who died of a cerebrovascular accident. This section illustrates a typical islet supplied by a single arteriole (arrows). Note the multiple endocrine-exocrine capillary connections (haematoxylin and eosin, $\times 230$ )

formly atrophic according to the islet type (Fig. 2). Where insulin-containing and insulin-deficient islets were juxtaposed, the zonal nature of the atrophy could be readily appreciated (Fig. 3). Thus, the relative area of normal and atrophic exocrine tissue in any section was entirely related to the relative number of insulin-containing and insulin-deficient islets. It was of interest that in patient 11 , where there had been insulin treatment for 6 years, only one lobule of the pancreas had normal acinar tissue, and in this lobule all seven islets contained insulin All the remaining islets in this case were insulindeficient.

\section{Discussion}

The exact pathogenesis of Type 1 diabetes remains uncertain, but approximately $85 \%$ of patients have circulating cytoplasmic islet cell antibodies at presentation [9]. These antibodies have been detected up to 3 years before clinical manifestion of diabetes [10], suggesting a prolonged latent period for the disease. Since pathological material is not available during this latent period, the best chance of observing the morphological appearances of the disease in the pancreas is in patients who die at or near presentation. Such recent-onset subjects form the basis of the present study. That they outnumber the more prolonged duration patients may seem surprising, but several factors may have contributed to this. Firstly, the hospital under survey only treats children under the age of 13 years. Secondly, many of the children included were extremely ill on admission and no diagnosis had been made in the community, and thirdly, there may have been an understandable reluctance to request autopsies on diabetic children who had been treated for several years.

No exact morphometric techniques could be used in this study since the weight of pancreas and site of histological sampling were unknown in most cases. However, it was apparent that there was a large number of insulin-deficient islets in all the pancreases studied and that many insulin-containing islets were hypertrophic. The insulin-deficient islets appeared to contain approximately two-thirds A cells, one-third D cells and occasional PP cells and thus they appeared to be the result of selective B cell loss. These findings are in agreement with previous reports $[4,11]$.

In the present study, eight out of nine recent-onset patients had demonstrable insulitis. This is the highest incidence of insulitis yet reported - a finding which may be due to the age of the patients concerned. When the results of two previous studies are combined, it can be seen that all 12 patients under the age of 13 years with recent-onset diabetes had insulitis, while in the 15 patients over that age insulitis was present in only five $[3,4]$. In addition to cytoplasmic islet cell antibodies, which are directed against $A$ and $D$ cells as well as B cells [9], islet cell surface antibodies are also found in Type 1 diabetes and these have been shown to lyse cultured rat B cells in preference to A, D and PP cells [12]. This finding may correspond with the presence of insulitis particularly affecting islets containing insulin, which was shown in the present study. Such a relationship was apparent in one patient studied by Gepts and De Mey [4] and supports the concept of a specific, immunologically mediated destruction of $B$ cells in the pathogenesis of Type 1 diabetes.

The appearance in the exocrine tissue of acinar cell atrophy confined to the vicinity of insulin-deficient islets has not been reported previously. It is perhaps explicable through a knowledge of the vascular anatomy of islets and the effects of islet hormones on pancreatic exocrine tissue [13]. In several animal species [13], including man [14, 15 and Fig. 4], pancreatic islets have been shown to be supplied by arterioles which form relatively wide sinusoids within the islet. Endocrine-exocrine connecting vessels allow flow of blood directly from these sinusoids to capillaries ramifying in the adjacent exocrine tissue. This direction of flow has been 
confirmed in vivo in the rabbit [16]. As a result, the exocrine tissue around islets is reckoned to be exposed to concentrations of islet hormones several hundred times greater than those found in the systemic circulation [16]. Insulin and pancreatic polypeptide are both thought to be trophic hormones for the exocrine pancreas. Insulin increases the rate of protein synthesis and cell division in the acinar tissue [13], and pancreatic polypeptide has been shown to increase DNA synthesis in rat pancreatic acinar cells [17]. By contrast, glucagon and somatostatin inhibit exocrine function [13] and prolonged parenteral administration of glucagon to rats caused pancreatic acinar atrophy [18]. All pancreatic sections in the present study were taken from the glucagon-rich lobe of the pancreas which constitutes $90 \%$ of the volume of the normal gland [11]. Here PP cells form only approximately $1 \%$ of the endocrine cells [11] and thus blood leaving insulin-deficient islets will probably contain high levels only of glucagon and somatostatin, resulting in atrophy of surrounding acini. On the other hand, blood leaving insulin-containing islets, where there is evidence of B cell hypertrophy and hyperfunction [1], will presumably contain abundant insulin in addition to the other hormones and hence no atrophy is seen around these islets. In long-standing Type 1 diabetes, there is a two-thirds reduction in the weight of the glucagon-rich lobe [19] - a finding which can be explained by the present hypothesis. It has been shown that the PP-rich lobe, lying in the dorsal part of the pancreatic head, does not atrophy in such patients, in spite of loss of B cells [19]. The probable explanation for this is that here $95 \%$ of the endocrine cells in insulin-deficient islets are PP cells [11] which can continue to exert a trophic effect on the surrounding exocrine tissue [19].

There is a functional counterpart to the pancreatic atrophy found in Type 1 diabetes. Such patients have a progressive degree of exocrine deficiency, approaching that found in patients who have chronic pancreatitis but no secondary diabetes [20]. Patients who have residual insulin secretion have better preserved exocrine function than those who do not [21]. Here, pancreatic acini would be expected to be normal in the vicinity of insulin-containing islets, as found in patient 11 of the present study.

Acknowledgements. Sincere thanks are expressed to Drs. A.Gibson and A. Patrick for the use of material from the Royal Hospital for Sick Children and to Dr. B. Frier for helpful discussion. The technical help of Mr. N. Collins, Mr. A. McMillan and Mr. P. Kerrigan has been greatly appreciated.

\section{References}

1. Gepts W (1965) Pathologic anatomy of the pancreas in juvenile diabetes mellitus. Diabetes 14: 619-633

2. Doniach I, Morgan AG (1973) Islets of Langerhans in juvenile diabetes mellitus. Clin Endocrinol 2: 233-248
3. Junker K, Egeberg J, Kromann H, Nerup J (1977) An autopsy study of the islets of Langerhans in acute-onset juvenile diabetes mellitus. Acta Pathol Microbiol Scand Sect A 85: 699-706

4. Gepts W, De Mey J (1978) Islet cell survival determined by morphology - an immunocytochemical study of the islets of Langerhans in juvenile diabetes mellitus. Diabetes 27 (Suppl 1): 251-261

5. MacLean N, Ogilvie RF (1959) Observations on the pancreatic islet tissue of young diabetic subjects. Diabetes 8: 83-91

6. Le Compte PM, Gepts W (1977) The pathology of juvenile diabetes. In: Volk BW, Wellmann KF (eds) The diabetic pancreas. Plenum Press, New York, pp 325-363

7. Burns $\mathbf{J}$ (1978) Immunohistological methods and their application in the routine laboratory. In: Anthony PP, Woolf N (eds) Recent advances in histopathology, No.10. Churchill Livingstone, Edinburgh, pp 337-350

8. Sternberger LA, Hardy PH, Cucullis JJ, Meyer HG (1970) The unlabelled antibody enzyme method of immunohistochemistry: preparation and properties of soluble antigen-antibody complex (horseradish peroxidase - anti-horseradish peroxidase) and its use in the identification of spirochaetes. J Histochem Cytochem 18: 315-333

9. Lendrum R, Walker G, Cudworth AG, Theophanides C, Pyke DA, Bloom A, Gamble DR (1976) Islet-cell antibodies in diabetes mellitus. Lancet 2: 1273-1276

10. Gorsuch AN, Spencer KM, Lister J, McNally JM, Dean BM, Bottazzo GF, Cudworth AG (1981) Evidence for a long prediabetic period in Type 1 (insulin-dependent) diabetes mellitus. Lancet 2: 1363-1365

11. Stefan Y, Orci L, Malaisse-Lagae F, Perrelet A, Patel Y, Unger RH (1982) Quantitation of endocrine cell content in the pancreas of nondiabetic and diabetic humans. Diabetes 31:694-700

12. Doberson MJ, Scharff JE (1982) Preferential lysis of pancreatic Bcells by islet cell surface antibodies. Diabetes $31: 459-462$

13. Henderson JR, Daniel PM, Fraser PA (1981) The pancreas as a single organ: the influence of the endocrine upon the exocrine part of the gland. Gut 22: 158-167

14. Vandamme JP, Vand der Schueren G, Bonte J (1968) Vascularisation du pancreas: proposition de nomenclature PNA et angioarchitecture des ilots. CR Assoc Anat 139: 1184-1192

15. Sapin MR, Vdovin VF (1981) Anatomy of the islets of the pancreas in association with their vascularisation. Folia Morphol 29: $100-103$

16. Fraser PA, Henderson JR (1980) The arrangement of endocrine and exocrine pancreatic micro circulation observed in the living rabbit. Q J Exp Physiol 151-158

17. Greenberg GR, Mitznegg P, Bloom SR (1977) Effect of pancreatic polypeptide on DNA-synthesis in the pancreas. Experientia 33: $1332-1333$

18. Salter JM, Davidson IWF, Best CH (1957) The pathological effects of large amounts of glucagon. Diabetes 6: 248-252

19. Rahier J, Wallon J, Loozen S, Lefevre A, Gepts W, Haot J (1983) The pancreatic polypeptide cells in the human pancreas: the effects of age and diabetes. J Clin Endocrinol Metab 56: 441-444

20. Frier BM, Saunders JHB, Wormsley KG, Bouchier IAD (1976) Exocrine pancreatic function in juvenile-onset diabetes mellitus. Gut 17:685-691

21. Frier BM, Faber OK, Binder C, Elliot HL (1978) The effect of residual insulin secretion on exocrine pancreatic function in juvenile-onset diabetes mellitus. Diabetologia 14: 301-304

Received: 9 August 1983

and in revised form: 16 March 1984

Dr. Alan K. Foulis

Department of Pathology

Glasgow Royal Infirmary

Castle Street

Glasgow G4 OSF

UK 